\title{
ASSESMENT OF BIOACTIVITY OF A FISCHERELLA SPECIES COLONIZING AZADIRACHTA INDICA (NEEM) BARK
}

\author{
S. K. TRIGUN ${ }^{1}$ * A. P. SINGH ${ }^{2}-$ R. K. ASTHANA ${ }^{2}-$ S. M. PANDEY ${ }^{1}-$ P. PANDEY $^{1}-$ \\ S. K. SINGH ${ }^{1}-$ S. P. SINGH ${ }^{2}$ \\ *e-mail: sktrigun@sify.com \\ ${ }^{1}$ Biochemistry \& Molecular Biology Section, Department of Zoology, BHU, Varanasi-221005, \\ India \\ ${ }^{2}$ Department of Botany, Banaras Hindu University, Varanasi-221005, India \\ (phone +91-0542-2575199(R); fax +91-0542-2368174) \\ *Corresponding author \\ (Received $11^{\text {th }}$ March 2005, accepted $4^{\text {th }}$ August 2005)
}

\begin{abstract}
In order to investigate whether a. Fischerella sp. colonizing Azadirachta indica (neem) bark is able to show, like neem derived extracts/products, bioactivity with respect to glucose metabolizing potential in animal models, laboratory cultivated neem colonized cyanobacterial biomass was fed to mice and its effects on liver lactate dehydrogenase (LDH: a key enzyme of glucose metabolism) vis a vis blood glucose level was monitored. Neem bark extract and purified azadirachtin (a bioactive neem product) were also tested simultaneously for comparison. As compared to the control, none of the samples could produce much variation in blood glucose levels except a transitory decline, $34 \%$ and $26 \%$ at $2^{\text {nd }} \& 12^{\text {th }} h$, in azadirachtin and Fischerella (isolated from neem) fed mice respectively. However, all the test samples showed significant increase in liver LDH activity after $2 \mathrm{nd}$ h of treatment $(\mathrm{p}<0.01)$ followed by a decline at 6 th $\mathrm{h}$. Thereafter, the enzyme activity increased progressively up to $24^{\text {th }} \mathrm{h}$ in mice fed with azadirachtin and neem colonized Fischerella only $\left(\mathrm{p}<0.001\right.$ at $\left.24^{\text {th }} \mathrm{h}\right)$. Expression pattern of the enzyme was also studied using polyacrylamide gel electrophoresis. Liver specific M4-LDH (homo-tetramer of M sub-unit) was detected in all the cases and time-dependent changes in expression of the enzyme paralleled the alterations observed in its activities. To ascertain whether such a bioactivity is common with Fischerella sp. colonizing other trees also, liver LDH profile was compared between mice fed with Fischerella isolated from neem and jamun (Eugenia jambolana) barks separately. Though Fischerella from jamun did not alter liver LDH profile, Fischerella isolated from neem could produce significant increase in the enzyme activity $(p<0.001)$ and corresponding changes in the expression of LDH isozymes. The results suggest that Fischerella sp. inhabiting neem bark, like bioactivity of its host plant products, modulates activity and expression of liver LDH in mice.
\end{abstract}

Keywords: Fischerella, Cyanobacterium, glucose metabolism, lactate dehydrogenase, azadirachtin

\section{Introduction}

Cyanobacteria, occupying wide ecological niches, also colonize as epiphytes on neem (Azadirachta indica) and other plants in the tropics. Neem derived extract/products have been found potent glucose mobilizers in hyperglycemic animal models $[1,2]$. Certain cyanobacteria have been reported to produce specific bioactive molecules such as antibiotics [3] and antioxidants [4,5]. Some of them have also shown the ability of altering their metabolic activities under different conditions [6-8]. Therefore, a rarely screened niche for cyanobacteria, the neem bark, prompted us to explore the bioactivity of a cyanobacterium inhabiting this plant with regard to glucose metabolizing potential in a. mammal. ]

LDH (EC 1.1.1.27) is one of the most susceptible glucose metabolizing enzymes to show changes due to glucose utilization dependent pathological conditions in animal models [9-11]. In normal (non-pathogenic) animals also, LDH acts as marker enzyme for metabolic adaptations due to environmental changes [12,13], physiological 
alterations $[14,15]$ and chemical treatments $[16,17]$. Therefore, monitoring the profile of liver LDH in mice was selected as main parameter for the present study.

So far metabolic role of the algal biomass is concerned, feeding a red microalge to chickens has reportedly reduced serum cholesterol level and modulated lipid composition of its egg yolk [18]. However, biochemical basis of such changes and other relevant studies of this kind in mammals have not been addressed much. Particularly, implications of epiphytic cyanobacteria as metabolic modulators in mammals are largely unexplored.

Therefore, the aim of this study was to assess bioactive potential of Fischerella sp. isolated from neem bark, with respect to modulating LDH, one of the key enzymes of glucose metabolism, in mice liver.

\section{Materials and methods}

All the chemicals used were of analytical grade. $\beta$-NADH ( $\beta$-nicotinamide adenine dinucleotide, reduced), sodium pyruvate and azadirachtin were purchased from Sigma Chemical Co, USA..

\section{Cultivation of epiphytic cyanobacterium}

The diazotrophic cyanobacterium Fischerella sp. isolated from neem or jamun bark was grown separately in modified Chu-10 medium [19] under continuous tungsten plus fluorescent illumination $\left(14.4 \mathrm{w} / \mathrm{m}^{2}\right)$ at $30 \pm 1^{\circ} \mathrm{C}$. The medium was free from any combined nitrogen sources. The cyanobacterial cultures were also subjected to tests for axenic nature adopting the method of Venkatraman [20]. Log phase algal culture was shaken vigorously with the sterile glass beads. A drop of the suspension was inoculated on agar plates containing $0.5 \%$ dextran, $0.2 \%$ yeast extract and $0.2 \%$ bacteriological peptone. Following dark incubation at $25^{\circ} \mathrm{C}$, these plates were monitored for the development of bacterial lawn up to 7 days. The uninfected cyanobacterial cultures, screened through this test, were taken as axenic.

\section{Preparation of experimental samples}

Cyanobacterium was cultivated in batch culture using 1 liter 15 flasks to obtain enough biomass. Log phase Fischerella cells (10g fresh wt.) were washed, centrifuged, lyophilized (Martin Christ, GmbH, Germany) and stored at $4 \pm 2{ }^{\circ} \mathrm{C}$. Before feeding, the biomass was ground to fine powder, dissolved in $100 \mathrm{ml}$ distilled water and stored refrigerated.

Neem bark $(10 \mathrm{~g})$ was cleaned with distilled water and whipped thrice with $90 \%$ alcohol followed by 2-3 washes in sterile distilled water. It was ground to fine powder, dissolved in $100 \mathrm{ml}$ sterile double distilled water, filtered through Whatman 1 paper, air dried and stored refrigerated.

\section{Animal}

Adult male mice (AKR strain) of same age group were used for the experiments. These were bred and reared under laboratory conditions $\left(25-30^{\circ} \mathrm{C}\right)$ as per the recommendations of the 'laboratory animals division', Central Drug Research Institute (CDRI) Lucknow, India, under the supervision of the 'laboratory animal welfare committee' of the University. 


\section{Treatment of experimental mice}

Pilot experiments were performed to assess physiological acceptability and suitable dose of the samples in mice. To avoid the interference of circadian rhythmicity, the samples feed were orally administered at a fix time of the day. For the first set of experiments, mice were divided in four groups consisting of 4-5 animals in each group. Groups 1 and 2 were orally administered with $10 \mathrm{mg}$ equivalents of cultivated neem colonized Fischerella and neem bark extract respectively, $3^{\text {rd }}$ group was given with $4 \mu \mathrm{g}$ of purified azadirachtin. The control mice (group 4) were orally administered with the equal volume of double distilled water. In the second set, $1^{\text {st }}$ and $2^{\text {nd }}$ group of mice were orally administered with $10 \mathrm{mg}$ of dissolved Fischerella sp. isolated from neem and jamun barks separately once in a day up to 7 days. The $3^{\text {rd }}$ group was accordingly given the equivalent volume of double distilled water and treated as control. All treatments were done immediately after giving regular food. After a gap of $1.5 \mathrm{~h}$, the mice were left on normal food and water supply, and 3-4 animals from each group were sacrificed at indicated time points.

\section{Preparation of liver extract}

The first experimental set mice were sacrificed at 2, 6, 12 and $24 \mathrm{~h}$ after the treatment. Mice of second set were sacrificed after 7 days of continuous treatment. Blood from 3-4 animals was pooled in a heparinised tube for glucose estimation. Liver tissue was dissected out, washed in ice-cold normal saline $(0.9 \% \mathrm{NaCl})$ and homogenized $(10 \%)$ in $20 \mathrm{mM}$ Tris-Cl buffer $(\mathrm{pH} \mathrm{7.4)}$ in cold room using PotterElvehjen homogenizer. The extracts were centrifuged at $14,000 \mathrm{xg}$ for $20 \mathrm{~min}$. at $4^{\mathrm{O}} \mathrm{C}$ and supernatants were used for the further experiments.

\section{LDH assay}

LDH was assayed according to Kornberg [21] and Prabhakaram and Singh [14]. The reaction mixture $(3 \mathrm{ml})$ was composed of $20 \mathrm{mM}$ Tris- $\mathrm{Cl}(\mathrm{pH} 7.4), 6 \mathrm{mM}$ NADH, suitably diluted liver extract and $1 \mathrm{mM}$ sodium-pyruvate. The decrease in absorbance at $340 \mathrm{~nm}$ was recorded up to $10 \mathrm{~min}$. The oxidation of $1 \mu$ mole of NADH per min at $25^{\mathrm{O}} \mathrm{C}$ was defined as 1 unit of the enzyme and values were presented as unit $\mathrm{g}^{-1}$ wet wt. of tissue \& unit $\mathrm{mg}^{-1}$ protein.

Statistical analyses of the data were done following Bruning and Kintz [22]. Student ' $t$ ' test was performed to find the level of significant changes (control vs experimental groups).

Estimation of protein in the tissue samples was done adopting the method of Lowry et al. [23]. Glucose estimation was done following glucose oxidase method [24] using the kit supplied by Span Diagonistics Ltd., India.

\section{Polyacrylamide gel electrophoresis (PAGE)}

Non-denaturing PAGE was carried out according to Davis [25] in a cold room with a constant current of $30 \mathrm{~mA}$ applied to a $7 \times 7 \mathrm{~cm}$ slab gel for $2 \mathrm{~h}$. Gels were developed in an activity stain mixture at $37^{\circ} \mathrm{C}$ following the method of Dietz and Lubrano [26]. The staining mixture $(20 \mathrm{ml})$ consisted of $125 \mathrm{mM}$ Tris- $\mathrm{Cl}(\mathrm{pH} 7.4), 0.5 \mathrm{mM} \mathrm{MgCl} 2,100 \mathrm{mM}$ $\mathrm{NaCl}, 100 \mathrm{mM}$ Li-lactate, $1 \mathrm{mg} \mathrm{ml}^{-1}$ NAD (nicotinamide adenine dinucleotide, oxidized), $0.25 \mathrm{mg} \mathrm{ml}^{-1} \mathrm{NBT}$ (nitroblue tetrazolium) and $0.25 \mathrm{mg} \mathrm{ml}^{-1} \mathrm{PMS}$ (phenazine methosulphate). After development of LDH bands, gels were kept overnight in triple distilled water. 


\section{Results}

\section{Effect on blood glucose level}

To ascertain whether any of the experimental samples changes glucose homeostasis in normally fed mice, blood glucose was measured in control and treated groups. Since, enough blood could not be collected from one mice, estimations are based on the pooled blood from 3-4 animals as one sample at each time point and mean \pm SE from 3 such assays has been presented in Table1.

Table 1. Time course of blood glucose level in control mica and those fed with azadirachtin, neem bark extract and Fischerella isolated from neem bark

\begin{tabular}{|l|c|c|c|c|}
\hline \multicolumn{1}{|c|}{ Treatment } & \multicolumn{4}{|c|}{ Blood glucose $\mathbf{m g ~ d l}^{-\mathbf{1}}$ ) } \\
\hline $\begin{array}{l}\text { Untreated } \\
\text { (control) }\end{array}$ & $178.80 \pm 1.47$ & $143.90 \pm 2.54$ & $146.46 \pm 0.99$ & $176.83 \pm 4.19$ \\
\hline Azadirachtin & $118.26 \pm 1.79^{\text {th }} \mathbf{h}$ & $132.30 \pm 2.23$ & $159.60 \pm 3.52$ & $156.86 \pm 4.25$ \\
\hline $\begin{array}{l}\text { Neem bark } \\
\text { extract }\end{array}$ & $170.30 \pm 1.26$ & $142.90 \pm 2.92$ & $145.90 \pm 3.11$ & $159.36 \pm 3.57$ \\
\hline $\begin{array}{l}\text { Fischerella } \\
\text { isolated } \\
\text { from neem }\end{array}$ & $170.40 \pm 3.34$ & $159.70 \pm 8.09$ & $107.90 \pm 2.42^{*}$ & $175.73 \pm 4.16$ \\
\hline${ }^{*} p<0.05$ (control & \multicolumn{5}{|l|}{ Vs respective treated group). } \\
\hline
\end{tabular}

In the control mice, though blood glucose level was highest $(178 \mathrm{mg} \mathrm{dl}-1)$ at $2^{\text {nd }} \mathrm{h}$, it showed a decrease $\left(\sim 146 \mathrm{mg} \mathrm{dl}^{-1}\right)$ between $6-12^{\text {th }} \mathrm{h}$ followed by recovery of its $2^{\text {nd }} \mathrm{h}$ value at $24^{\text {th }} \mathrm{h}$. Mice fed with all the experimental samples also showed blood glucose level in the close range of the control values except a transitory decline in case of azadirachtin $(34 \%)$ and neem colonized Fischerella $(26 \%)$ fed mice at $2^{\text {nd }} \& 12^{\text {th }} \mathrm{h}$ respectively.

\section{Effect on LDH activity:}

As liver is the main site of glucose metabolism, the profile of liver LDH is generally correlated with glucose turnover efficiency of the tissue. In the control mice, liver LDH activity increased slightly from $2^{\text {nd }}$ to $6^{\text {th }} \mathrm{h}$ and could maintain the same level thereafter up to $24^{\text {th }} \mathrm{h}$ (Figure 1 ). In comparison, the enzyme level increased significantly $(\sim 1.5$ times, $p<0.01)$ at $2^{\text {nd }} h$, followed by a decline at 6 th $h$ and the recovery over its $2^{\text {nd }} h$ value by $12^{\text {th }} \mathrm{h}$ after feeding all the experimental samples. Although, mice fed with neem extract could maintain the same level thereafter, a significant further increase in LDH activity $(\mathrm{p}<0.001)$ was observed at $24^{\text {th }} \mathrm{h}$ in mice groups fed with neem colonized Fischerella and azadirachtin samples.

\section{Effect on the expression of liver LDH:}

To verify whether the experimental samples affect expression of LDH in mice liver for bringing out changes in its activity, the enzyme extracts (pooled from 3 animals) were subjected to native PAGE. LDH band developed was identified as the most cathodic M4-LDH after comparing its mobility with those of the five known LDH isozymes from other tissues (unpublished result). According to Figure 2, only M4-type 
was expressed in liver of control as well as experimental mice. The intensities of LDH bands increased remarkably from $2^{\text {nd }} \mathrm{h}$ to $6^{\text {th }} \mathrm{h}$ onwards in control group and corroborated well with the activity profile (Figure 1, control line). Similarly, in comparison to the control ( $2^{\text {nd }} \mathrm{h}$ lane), expression of LDH showed $\sim 2$ - 4 times increase at $2^{\text {nd }} \mathrm{h}$ after the treatment with all the experimental samples. Thereafter, though LDH bands from neem extracts and azadirachtin treated mice showed comparable alterations with their activity profiles at different time points, mice fed with neem colonized Fischerella could show $\sim 3-4$ times consistent increase in the expression of M4-LDH up to $24 \mathrm{~h}$ of treatment.

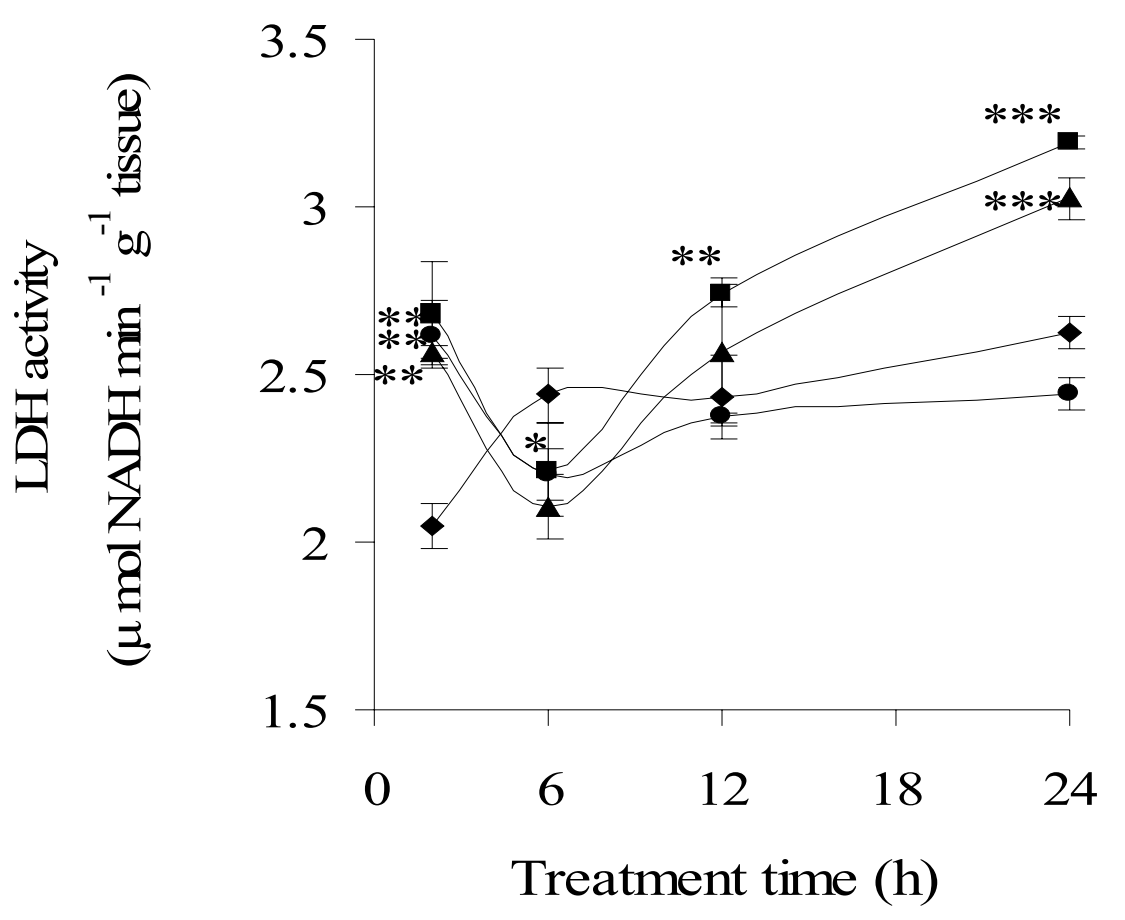

Figure 1. Time course of LDH activity in liver extracts from $\longrightarrow$ control mice and those fed with $\boldsymbol{\Lambda}-\boldsymbol{\Lambda}$ azadirachtin; - neem bark extract; - Fischerella isolated from neem. Mean $\pm S D$ from 3-4 animals has been presented. ${ }^{*} p<0.02,{ }^{* *} p<0.01, * * * p<0.001$ represent level of significant changes (control vs experimental groups).

\section{LDH modulating effects of Fischerella isolated from neem and jamun barks:}

To ascertain whether LDH modulating effect is common in other epiphytic Fischerella also, effects of laboratory cultivated Fischerella from neem and jamun barks on LDH profile were compared after feeding these samples to separate group of mice up to 7 days. According to Figure 3 A \& B, in comparison to the control, mice treated with Fischerella from jamun bark did not show any change in the activity and expression of liver LDH. However, Fischerella isolated from neem could produce $\sim 1.5$ times increase in the enzyme activity $(\mathrm{p}<0.001)$, parallel to an appreciable increase in the expression of M4-LDH. It also showed the appearance of other H-subunits containing LDH isozymes but with reduced intensity. 


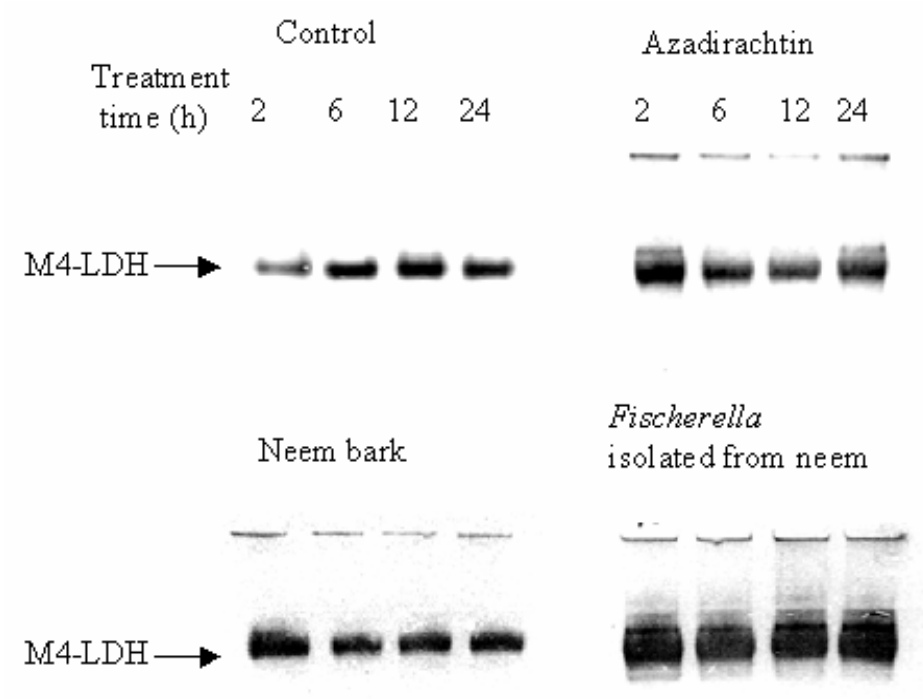

Figure 2. LDH expression pattern at different time points in the liver of control mice and those fed with azadirachtin, Neem bark extract and Fischerella isolated from neem. Each lane represents $25 \mu \mathrm{g}$ protein run on $8 \%$ non-denaturing PAGE.

\section{LDH modulating effects of Fischerella isolated from neem and jamun barks:}

To ascertain whether LDH modulating effect is common in other epiphytic Fischerella also, effects of laboratory cultivated Fischerella from neem and jamun barks on LDH profile were compared after feeding these samples to separate group of mice up to 7 days. According to Figure 3 A \& B, in comparison to the control, mice treated with Fischerella from jamun bark did not show any change in the activity and expression of liver LDH. However, Fischerella isolated from neem could produce $\sim 1.5$ times increase in the enzyme activity $(\mathrm{p}<0.001)$, parallel to an appreciable increase in the expression of M4-LDH. It also showed the appearance of other H-subunits containing LDH isozymes but with reduced intensity.

\section{Discussion}

As neem derived products are known for their glucose mobilizing potential in animal models, similar parameters have been selected to assess the bioactivity of a microalge inhabiting this plant. Changes in the blood glucose level are known to modulate glucose metabolizing enzymes in animal tissues [9,27]. Nonetheless, most of these enzymes are modulated by a variety of external and endogenous factors at normo-glycemic conditions also [15-17, 28]. Therefore, in order to rule out the probable interference of blood glucose level in LDH modulating effects of Fischerella isolated from neem and other samples, routine feeding of the treated groups were continued so that these mice maintain normal glycemic condition, if otherwise not affected by the samples. A close range of blood glucose level in control as well as all the experimental mice (Table 1) suggests that even neem extract and azadirachtin, known for their hypoglycemic actions in diabetic animals [2], do not alter normal glucose homeostasis in non-pathogenic mice. On overall pattern, it is true for Fischerella isolated from neem also. Although a 
transitory small decline in blood glucose level at $2^{\text {nd }}$ and $12^{\text {th }} \mathrm{h}$, due to the treatment with azadirachtin and neem colonized Fischerella respectively, is observed, it is not sufficient to ascribe hypoglycemic effects of these samples in normal mice.

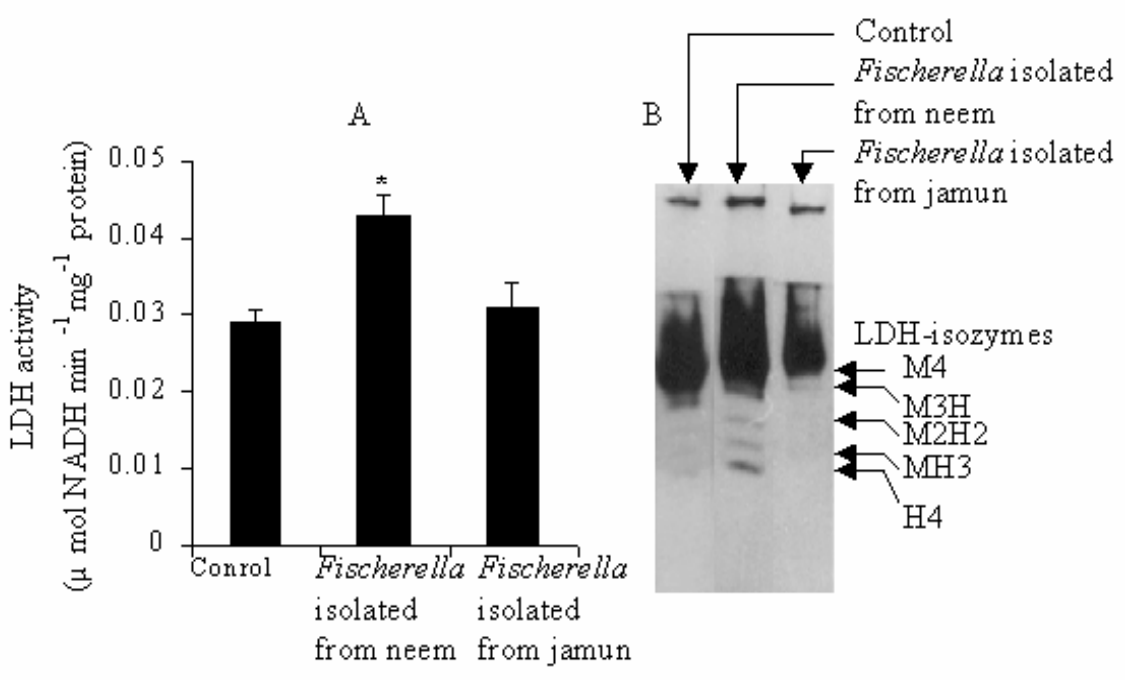

Figure 3. Activity profile (A) and expression pattern of $L D H(B)$ in the liver of control mice and those fed with the Fischerella sp. isolated from neem and jamun barks up to 7 days. Mean $\pm S D$ from 3-4 animals has been presented in $A .{ }^{*} p<0.001$ (control vs experimental group). $B$ represents the results of $30 \mu$ protein run on $10 \%$ non-denaturing PAGE in each lane

While correlating blood glucose levels with LDH profiles, in case of untreated mice (Figure 1, control line), increased enzyme activity at $6^{\text {th }}$ and $12^{\text {th }} \mathrm{h}$ from a minimum value at $2^{\text {nd }} \mathrm{h}$, shows an inverse relationship with a slight decrease in blood glucose (Table1, control values), and thus, indicates for a normal circadian pattern of glucose metabolism in mice liver. However, this pattern is not maintained in mice fed with all the experimental samples. Significant bi-phasic increase in liver LDH activity (Figure 1) in these groups do not correlate with the subtle changes in blood glucose levels.

Inverse relationship between the increased blood glucose level and tissue LDH activity has been reported in diabetic animal models $[9,11]$. Although, a transitory decline in blood glucose level in mice fed with azadirachtin and neem colonized Fischerella (Table 1) coincides with the significant increase in liver LDH activities at corresponding time points (Figure 1), none of these samples could cause uniform inverse relationship between blood glucose and liver LDH profiles. Therefore, it is hard to predict physiological implications of such transitory changes shown by these samples until further studies are made on pathogenic models. Nevertheless, bi-phasic significant increase in liver LDH activity between 2-24 h due to the treatment with azadirachtin and neem colonized Fischerella is uniformly evident. Thus, suggesting that irrespective of the subtle changes in blood glucose level, like neem extract and azadirachtin, Fischerella colonizing neem also shows strong LDH modulating activity in mice liver.

Changes in the enzyme activities are generally contributed either by interaction of an effecter to the enzyme or due to the changes in its expression. It has been demonstrated that mobility of M4-LDH gets retarded on gel electrophoresis if bound to some organic 
compounds [16]. According to Figure 2, M4-LDH from control as well as treated mice shows similar mobility, and thus, rule out the possibility of binding of an effecter to any of the enzyme samples. On the other hand, LDH genes bear inducible promoters [29] and have been found expressed differentially under a variety of conditions $[9,10,14,30]$. Therefore, increased expression of M4-LDH from 2 to $24 \mathrm{~h}$ in case of control mice and its differential pattern due to the treatment with all the samples seem to contribute for the corresponding changes in the enzyme activities. Likewise, $\sim 3-4$ times high expression of M4-LDH throughout the treatment, in case of mice fed with Fischerella isolated from neem, suggests preferential increase in the synthesis of LDH due to the treatment with the epiphytic cyanobacterium. The argument is further supported from Figure 3 A \& B, wherein, as compared to Fischerella isolated from jamun, neem colonized Fischerella, when fed up to a week, not only increased the abundance of M4$\mathrm{LDH}$ but also induced the expression of other $\mathrm{H}$-subunit containing isozymes in mice liver. This also suggests that LDH modulating activity of epiphytic Fischerella is niche specific.

Furthermore, such changes in LDH isozymes are considered the most reliable biochemical markers for glucose metabolizing status of a tissue under a variety of conditions $[9,10,14,15,30]$. Therefore, increased activity and expression of M4-LDH in mice fed with neem colonized Fischerella (Figure 2,3) seem to reflect for the glucose metabolizing potential of the epiphytic cyanobacterium in mice.

Feeding red algal biomass has been reported to alter serum cholesterol and triglycerides in birds [18]. However, such studies are scanty on mammals. Particularly, little is known about habitat specific bioactivity of the cyanobacteria. This article, the first study of such a kind, reports on the biochemical basis of the bioactivity (LDH modulating action) of a Fischerella sp. colonizing neem bark. At present, it is difficult to explain the role of neem in LDH modulating activity of Fischerella. Nevertheless, it is evident that like neem and azadirachtin (one of the neem products), Fischerella inhabiting neem bark also possesses LDH modulating properties in mice liver, and thus, appears to be a potential target for further studies on its physiological and medicinal implications in pathogenic animal models. Keeping into account of the appreciable changes in the expression of M4-LDH due to the treatment with the experimental samples, the present findings also provide a bioassay-guided tool for screening and isolation of bioactive factors, affecting glucose metabolism, from the cyanobacteria/other microorganisms inhabiting diverse habitats.

Acknowledgements: This work was financially supported from a major research project of CSIR No. 38(0964)/99/EMR-II, New Delhi to RKA and UGC - CAS program in Zoology. The authors thank Mr. R. Mishra for his help as a trainee in the lab of SKT and the Heads of Zoology and Botany departments, $\mathrm{BHU}$, for extending facilities for research collaboration of RKA \& SKT.

\section{REFERENCES}

[1] Bhargava A.K. (1987): Neem oil as a synergist to anti diabetic drugs for management of secondary hyperglycemia - Neem News Letter. 4: 31.

[2] El-Hawary Z.M., Kholief T.S. (1990): Biochemical studies on hypoglycemic agents (1) effect of Azadirachta indica leaf extract. - Arch. Pharmacol. Res. 13: 108.

[3] Doan N.T., Richards R.W., Rothschild J.M., Smith G.D. (2000): Allelopathic actions of the alkaloid 12-epi-hapalindole $\mathrm{E}$ isonitrile and calothrixin A from cyanobacteria of the genera Fischerella and Calothrix. - J. Appl. Phycol. 12: 409. 
[4] Romay C., Armesto J., Remirez D., Gonzalez R., Ledon N., Garcia, I. (1998): Antioxidant and anti-inflammatory properties of C-phycocyanin from blue-green algae. - Inflam. Res. 47: 36.

[5] Matsukawa R., Hotta M., Masuda Y., Chihara M., Karube, I. (2000): Antioxidants from carbon dioxide fixing Chlorella sorokiniana. - J. Appl. Phycol. 12: 263.

[6] Disch A., Schwender J., Müller C., Lichtenthaler H.K., Rohmer M. (1998): Distribution of the mevalonate and glyceraldehyde phosphate/pyruvate pathways for isoprenoid biosynthesis in unicellular algae and the cyanobacterium Synechocystis. - PCC 6714, Biochem. J. 333: 381.

[7] Schlegel I., Doan N.T., de Chazal N., Smith G.D. (1999): Antibiotic activity of cyanobacterial isolates from Australia and Asia against green algae and cyanobacteria. J. Appl. Phycol. 10: 471.

[8] Nogle L.M., Gerwick W.H. (2002): Somocystinamide A, a novel cytotoxic disulfide dimmer from a Fijian marine cyanobacterial mixed assemblage. - Org. Lett. 4: 1095.

[9] Aniscow E.K., Zhao C., Rutter G.A. (2000): Accute over-expression of LDH-A perturbs $\beta$-cell mitochondrial metabolism and insulin secretion. - Diabetes. 49: 1149.

[10] Niakan B. (2001): Repression of the enzyme lactate dehydrogenase and the spontaneous remission or regression of cancer. - Medical Hypothesis. 56: 693.

[11] Sandqvist M.M., Eriksson J.W., Jansson P.A.E. (2001): Increased lactate release per fat cell in normoglycemic first-degree relatives of individuals with type-2 diabetes. Diabetes. 50: 2344.

[12] Costa J.De., Alonso-Bedata M., Fraile, A. (1981): Temperature acclimation in amphibians: Changes in lactate dehydrogenase activities and isozymes patterns in several tissues from adult Discoglossus pictuis pictus (Oth). - Comp. Biochem. Physiol. 70B: 331.

[13] Prabhakaram M., Kaur J., Agarwal S., Agarwal A., Singh S.M., Singh, S.N. (1987): Properties of purified LDH from breast muscle of different birds adapted to various habitats. - Curr. Science. 56: 476.

[14] Prabhakaram M., Singh S.N. (1984): Alterations in rat LDH: Age-related comparison of M- and H-LDH. - Biochem. Int. 9: 399.

[15] Kanungo M.S. (1994): Changes in multiple forms of protein during ageing. - Genes and Ageing, Cambridge University press, London, p. 32.

[16] Lehnert T., Berlet H.H. (1979): Selective inactivation of lactate dehydrogenase of rat tissues by sodium deoxycholate. - Biochem. J. 177: 813.

[17] Mishra L., Singh A.K., Trigun S.K., Singh S.K., Pandey S.M. (2004): Anti-HIV and cytotoxic Ruthenium (II) complexes containing flavones: Biochemical evaluation in mice. - Ind. J. Exp. Biol. 42: 660.

[18] Ginzberg A., Cohen M., Sod-Moriah U.A., Shany S., Rosenshtrauch A., Arad S. (2000): Chickens fed with biomass of the red microalga Porphyridium sp. have reduced blood cholesterol level and modified fatty acid composition in egg yolk. - J. Appl. Phycol. 12: 325.

[19] Gerloff G.C., Fitzgerald G.P., Skoog F. (1950). The isolation, purification and culture of blue-green algae. - Am. J. Bot. 27: 216.

[20] Venkatraman G.S. (1969): Bacteria-free cultures, The cultivation of algae. - ICAR, New Delhi, p. 34.

[21] Kornberg A. (1955): Lactate dehydrogenase, Colowick S.P, Kaplan N.O. (Eds). Methods in Enzymology 1: 441.

[22] Bruning J.L., Kintze B.L. (1977): Supplemental computations for analysis of variance, pt.3, Computational Handbook of Statistics (2nd ed.). - Scott, Foresman \& Co., p. 107.

[23] Lowry O.H., Rosebrough N.J., Farr A.L., Randall R.J. (1951): Protein measurement with the Folin phenol reagent. - J. Biol. Chem. 193: 265.

[24] Tietz N.W. (1976): Clinical guide to laboratory tests. - WB Sanders Co; Philadelphia, p. 238. 
[25] Davis V.J. (1964): Disc electrophoresis: Methods and implication to human serum proteins. - Ann. N.Y. Acad. Sci. 121: 404.

[26] Dietz A.A., Lubrano T. (1967): Separation and quantification of lactate dehydrogenase isozymes by disc gel electrophoresis. - Anal. Biochem. 20: 246.

[27] Mayes P.A. (1988): Gluconeogenesis \& control of the blood glucose, Harper's Biochemistry (24th edition). - Prentice Hall International, Inc. p.194.

[28] Trigun S.K., Singh S.N. (1989): Age-linked alterations in fructose-2,6-bisphosphateinduced modulation of rat muscle phosphofructokinase. - Biochem. Int. 19: 1213.

[29] Hou E.W., Li S.S.L. (1987): Cyclic AMP induced expression of the mouse lactate dehydrogenase-A promoter-CAT fusion gene in Chinese hamster ovary wild type cells, but not in cAMP dependent protein kinase mutant cells. - Biochem. Biophys. Res. Commun. 147: 501.

[30] Prasad S.B., Giri A. (1999): Effect of cisplatin on the LDH activity and its isozymes pattern in dalton's lymphoma bearing mice. - Cytologia, 64: 259. 